\title{
RAPID CHARACTERIZATION OF S. mansOni EXPRESSION LIBRARY CLONES OF POTENTIAL INTEREST
}

\author{
Herminia Yohko KANAMURA(1) \& Kathy HANCOCK(2)
}

\begin{abstract}
SUMMARY
A S. mansoni adult worm cDNA expression library was screened with sera from baboons in a early phase after infection. The clones that were positive with the early infection sera were examined for reactivity with pre-infection sera and heterologous infection sera. In order to discriminate a positive antibody reaction from the reactivity due to residual anti- $E$. coli antibodies, an unrelated cDNA clone was plated with the positive clone. The unrelated clone provided the negative background and the contrast necessary to discern a positive antibody reaction. In this way, we were able to eliminate selected clones that were positive with the pre-infection sera or heterologous infection sera. This characterization of the expression library clones enabled us to quickly target only clones with the desired pattern of antibody reactivity for sequencing, subcloning, and expressing.
\end{abstract}

KEYWORDS: cDNA; Cloning; Expression; Lambda; Schistosoma.

When screening cDNA expression libraries with antibodies, it is desirable to confirm that the selected clones are the targeted clones before expending time and money on sequencing and expression. If the selected clones can be characterized with a small panel of antibodies, they can be evaluated in an assay that is a simple modification of the standard plaque screening assay' used to select the clones. The key of the method, which we refer to as the plaque expression assay, is the dilution of the selected clone in a background provided by an unrelated, negative clone. With the selected clone in a negative background, it is possible to discern the antibody reactivity of the clone when tested with a variety of sera. Without the negative clone providing the background reactivity, antibody reactivity is very difficult to discern (Fig. 1).

We developed the plaque expression assay while screening a Schistosoma mansoni cDNA expression library with very early infection sera in order to identify proteins that generate the initial immune response. The library was prepared from the poly A+ fraction of adult $S$. mansoni worms in the vector, lambda UniZap ${ }^{\mathrm{TM}} \mathrm{XR}^{*}$ (Stratagene, La Jolla, CA, USA). Standard methods were used for plating the bacteriophage on XL1-Blue Escherichia coli cells (Stratagene), inducing expression of the cloned genes with $0.33 \mathrm{mM}$ IPTG, immobilization of the plaques on nitrocellulose membranes, and
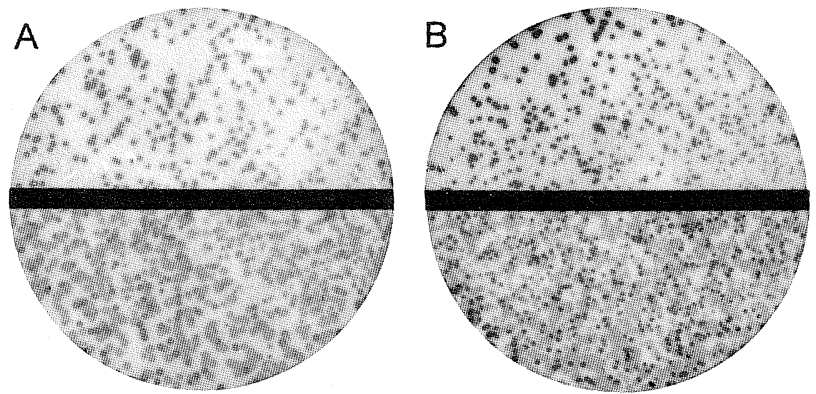

Fig. 1 - The antibody reactivity of Schistosoma mansoni clones with and without a negative clone background. The upper halves of each nitrocellulose filter contain a plaque-purified positive clone, the lower halves the same positive clone with the clone, Cryptosporidium parvum elongation factor 1-alpha, providing the negative background. Panel A shows clone A47, panel B, clone A40. All four filters were exposed to a pool of 9 to 11 week $S$. mansoni post-infection baboon sera.

detection of expressed genes using antibodies ${ }^{1,3}$. The library was screened with a pool of 4 week post-infection sera from four baboons, each infected with $350 \mathrm{~S}$. mansoni cercariae per $\mathrm{kg}$ body weight. The sera, at 4 weeks post-infection, were just beginning to exhibit antibody reactivity to adult worm antigens in a FAST-ELISA assay ${ }^{2}$ and had a level of antibody reactivity

\footnotetext{
* Use of trade names is for identification only and does not imply endorsement by the Public Health Service or by the U. S. Department of Health and Human Services. (1) School of Pharmaceutical Sciences, University of São Paulo, São Paulo, SP, Brazil and Department of Cellular Biology, University of Georgia, Athens, GA, USA.

(2) Centers for Disease Control and Prevention, Division of Parasitic Diseases, Atlanta, GA, USA.

Correspondence to: Dr. Herminia Yohko Kanamura. Faculdade de Ciências Farmacêuticas, Universidade de São Paulo. Av. Prof. Lineu Prestes 580, Bloco 17, 05508-900 São Paulo, SP, Brasil. Phone: 5511-818-3633. Fax: 5511-813-2197, e-mail: kanamura@usp.br.
} 
that was in the range of 5 to $10 \%$ of the antibody response exhibited at 10 weeks postinfection (data not shown). Positive clones were isolated by two rounds of plaque purification.

For the plaque expression assay, the positive clones were plated at a density of five to eight plaque forming units (pfu) per $\mathrm{cm}^{2}$ with a Cryptosporidium parvum elongation factor 1-alpha cDNA clone, also in lambda Uni-Zap XR, plated at a density of 16 to 20 pfu per $\mathrm{cm}^{2}$, providing the negative background. Sera for evaluating the clones was diluted 1:50 with $50 \mathrm{mM}$ Hepes, pH 7.2, 0.5\% Nonidet P40 (BDH Laboratory Supplies, England), $5 \%$ nonfat dry milk, $5 \mathrm{mg} / \mathrm{ml}$ E. coli lysate, $1 \mathrm{mM}$ Pefabloc $^{\circledR}$ SC (Boehringer-Mannheim, Indianapolis, IN, USA), $1 \mu \mathrm{g} / \mathrm{ml}$ Leupeptin (Calbiochem, La Jolla, CA, USA), $1 \mu \mathrm{g} / \mathrm{ml}$ Pepstatin A (Boehringer-Mannheim), and $0.1 \% \mathrm{NaN}_{3}$. The sera were absorbed with $E$. coli lysate by adding all of the above, except the nonfat dry milk, and rotating end over end at room temperature for one hour. The lysate was prepared from an overnight culture of XL1-Blue cells. Cells were washed with PBS then lysed by sonication in $0.05 \mathrm{M}$ Hepes, $\mathrm{pH} 7.2,0.5 \mathrm{M}$ $\mathrm{NaCl}, 0.5 \%$ Nonidet $\mathrm{P} 40,0.1 \% \mathrm{NaN}_{3}$, and protease inhibitors, as above. Nitrocellulose filters, with immobilized plaques, were washed with PBS with $0.3 \%$ Tween $^{\circledR} 20$ (Calbiochem) and 5\% nonfat dry milk (PBS/Tw/milk) for $2 \times 15$ min then exposed to sera absorbed with $E$. coli lysate and diluted as above. Bound antibodies were detected with goat anti-human immunoglobulin labeled with peroxidase ${ }^{4}$, diluted in PBS with $0.3 \%$ Tween 20 (PBS/Tw), followed by $0.003 \% \mathrm{H}_{2} \mathrm{O}_{2}$ (J.T. Baker, Phillipsburg,

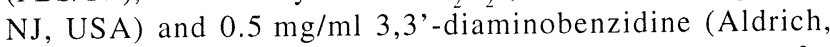
Milwaukee, WI, USA). Sera and conjugate incubations were for three hours at room temperature or overnight at $4^{\circ} \mathrm{C}$. After each incubation, the filters were washed $4 \times 5 \mathrm{~min}$ in PBS/Tw. Before substrate was added, the membranes were washed $3 \times 2 \mathrm{~min}$ with PBS to remove the Tween. Substrate was incubated for $10 \mathrm{~min}$ at room temperature and the reaction stopped by extensive washing with deionized $\mathrm{H}_{2} \mathrm{O}$.

The plaque-purified $S$. mansoni clones, selected with the early infection sera, were evaluated in the plaque expression assay. Clones were first tested with a pool of pre-infection sera from the four baboons, described above, to confirm that the antibody reactivity of the clones was due to an antibody associated with the infection (Fig. 2A, 2B and 2C). Of the eight clones tested with pre-infection sera, four clones reacted (for an example, see Figure 2C) and these clones were eliminated from further consideration. The remaining positive clones were then evaluated with a small panel of heterologous, parasitic human infection sera to confirm that the antibody reactivity of the clones was specific for schistosome infections (Fig. 2D).

Using the simple modification of including a negative clone in a standard plaque screening assay, we were able to gain three important pieces of information regarding our clones selected with infection sera. One, we confirmed that the plaque-purified clones racted with the antibody used to screen the library. The negative background provided the contrast necessary to discern a positive antibody reaction (Fig. 1). Two, we determined which of the positive clones reacted only with infection sera (Fig. 2A and $2 \mathrm{~B}$ ) and eliminated those which reacted with pre-infection sera (Fig. 2C). Three, we did a preliminary assay for specificity by testing the $S$. mansoni clones with infection sera from several other parasitic infections (Fig. 2D). By identifying positive clones that lacked the desired antibody reactivity characteristics before sequencing, subcloning, and expression, we were able to quickly target only the desired clones and to avoid the expenditure of a significant amount of effort pursuing clones that in the end would be of no interest.

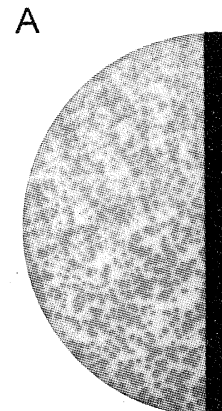

$(-)$

C

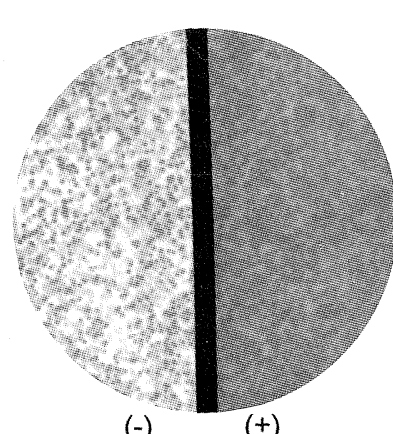

$(-)$

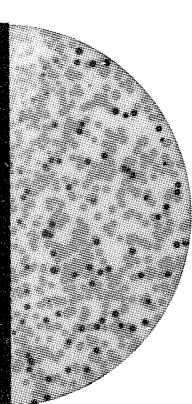

$(+)$

$(+)$

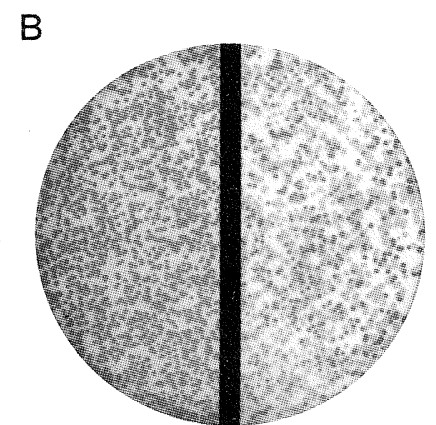

$(-)$

$\mathrm{D}$

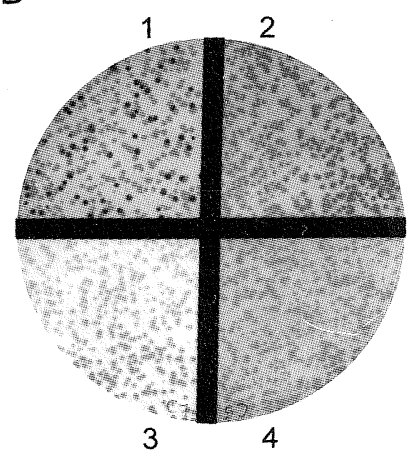

Fig. 2 - The antibody reactivity of Schistosoma mansoni clones with preinfection sera and with heterologous, parasitic infection sera. In all four panels, the plaque-purified positive clone is plated with the clone, Cryptosporidium parvum elongation factor 1 -alpha, providing the negative background. In panels A (clone B4), B (clone A47), and C (clone A46), the nitrocellulose filter on the left is probed with a pool of pre-infection sera $(-)$, the filter on the right with a pool of 9 to 11 week post-infection sera $(+)$. In panel D, clone A40 is probed with $S$. mansoni (1), cysticercosis (2), trichinosis (3), and echinococcosis (4) infection sera.

\section{RESUMO}

\section{Rápida caracterização dos clones de interesse isolados a partir de biblioteca de expressão do $S$. mansoni}

Uma biblioteca de expressão de cDNA de verme adulto de S. mansoni foi selecionada utilizando-se soros de macacos babuínos em fase inicial da infecção. Os clones que reagiram positivamente com os soros de infecção recente foram examinados quanto à reatividade contra soros normais e soros de infecção heteróloga. Com a finalidade de se conseguir melhor discriminação entre reatividade pośitiva com o anticorpo especí- 
KANAMURA, H. Y. \& HANCOCK, K. - Rapid characterization of S. mansoni expression library clones of potential interest. Rev. Inst. Med. trop. S. Paulo, 39(6): 355-357, 1997.

fico e aquela devido aos anticorpos anti-E. coli residuais, um clone de cDNA não relacionado ao $S$. mansoni foi plaqueado em mistura com o clone positivo. O plano de fundo negativo proporcionado pelo clone não relacionado forneceu o contraste necessário para discriminar a reação positiva específica. Esta metodologia de caracterização dos clones de expressão permite alcançar rapidamente os clones que apresentam o perfil de reatividade desejada, para posterior sequenciamento, subclonagem e expressão.

\section{ACKNOWLEDGEMENTS}

We thank Dr. Jeffrey W. Priest for his gift of the negative clone, Cryptosporidium parvum elongation factor 1-alpha in the vector lambda Uni-Zap XR, and Dr. Raymond T. Damian for his gift of the baboon sera. H. Y. Kanamura was supported by fellowship \#1 F05 TW05171 from the Fogarty International Center of the National Institutes of Health.

\section{REFERENCES}

1. AUSUBEL, F. M.; BRENT, R.; KINGSTON, R. E. et al. - Current protocols in molecular biology. New York, John Wiley, 1995.

2. HANCOCK, K. \& TSANG, V. C. W. - Development and optimization of the FAST-ELISA for detecting antibodies to Schistosoma mansoni. J. immunol. Meth., 92: 167-176, 1986.

3. SAMBROOK, J.; FRITSCH, E. F. \& MANIATIS, T. - Molecular cloning: a laboratory manual. New York, Cold Spring Harbor Laboratory Press; Plainview, 1989

4. TSANG, V. C. W.; GREENE, R. M. \& PILCHER, J. B. - Optimization of the covalent conjugating procedure $\left(\mathrm{NaIO}_{4}\right)$ of horseradish peroxidase to antibodies for use in enzyme-linked immunosorbent assay. J. Immunoassay, 16: 395-418, 1995.

Recebido para publicação em 25/06/1997

Aceito para publicação em 05/12/1997 
